31. Krutoviy, Z. A. Matematychne modelyuvannya retsepturnoyi kompozytsiyi keksu pidvyshchenoyi kharchovoyi tsinnosti [Text] / Z. A. Krutoviy, G. V. Zakharenko, L. O. Kasilova et. al. // Nauka ta innovatsiyi. - 2013. - Vol. 5, Issue 9. - P. 5-9.

32. Regulation (EU) № 854 of the European Parliament and of the Council. Laying down specific rules for the organisation of official controls on products of animal origin intended for human consumption [Text]. - Official Journal of the European Union, 2004. - 45 p.

33. Ovchinnikova, I. A. New methods of analysis of amino acids, proteins and peptydov [Text] / I. A. Ovchinnikova. - Moscow: Myr, 1974. - $120 \mathrm{p}$.

34. Otsenka nekotorykh pyshchevykh dobavok [Text]. - 37-y doklad Obedynennoho komyteta ékspertov FAO/VOZ po pyshchevym dobavkam. Seryya tekhnycheskykh dokladov VOZ: Geneva, 1994. - P. 27-39.

35. AACC International. Methods 10-50D and 10-52. Approved Methods of the American Association of Cereal Chemists, 10th ed. [Text]. - AACC International, St. Paul, MN, U.S.A., 2000.

36. Tkachenko, A. S. The forecasting of demand on the new sugar cookie with non-traditional raw-materials [Text] / A. S. Tkachenko // Materialy IV regionalnoiy conferencii: The goods of Lviv region on the today market: positioning, quality, safety within Eurointegration, 2015. - P. 220-224.

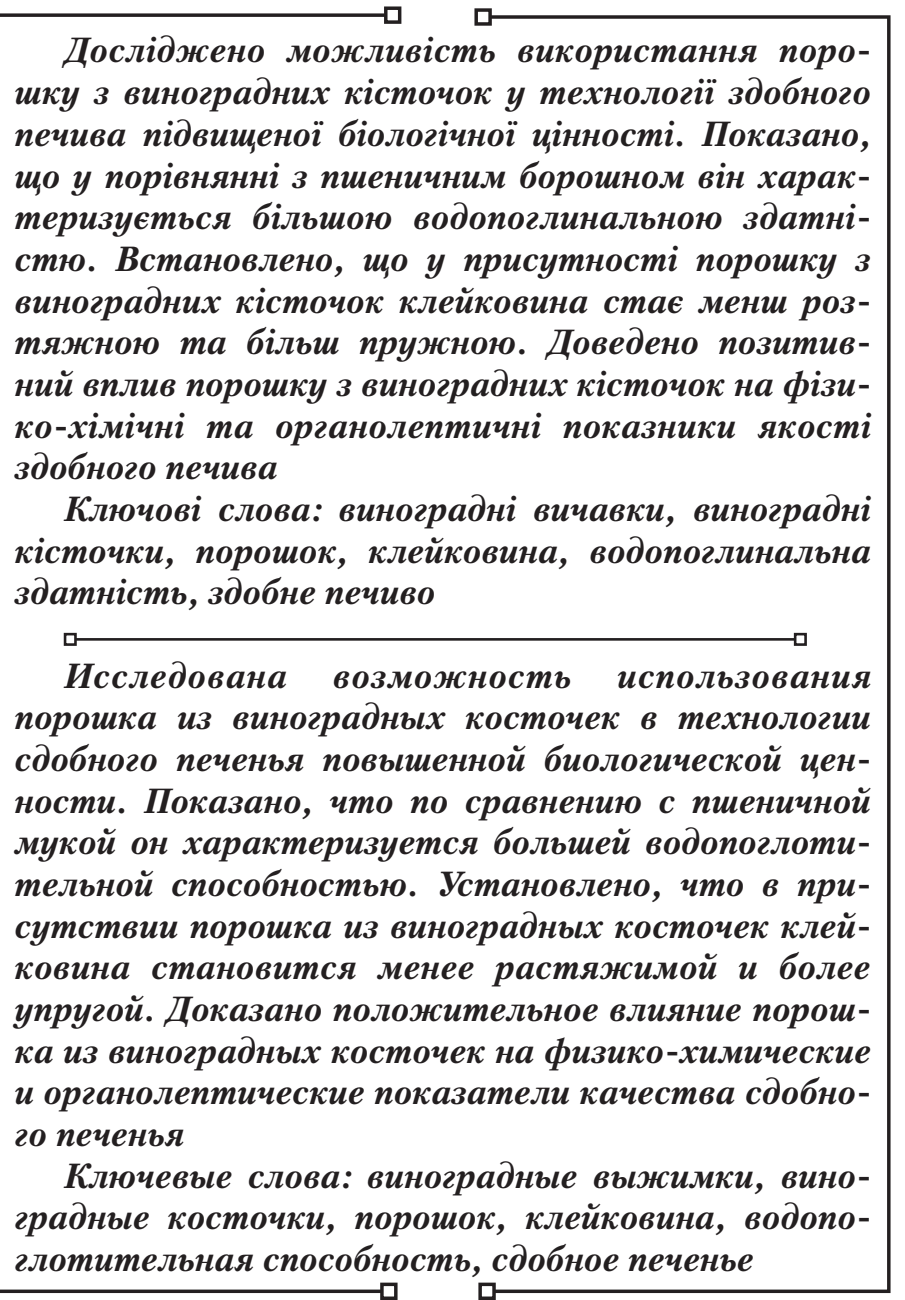

UDC 634.8: 664.682/.684

DOI: $10.15587 / 1729-4061.2016 .69838$

\section{THE EFFECT OF GRAPE SEED POWDER ON THE QUALITY OF BUTTER BISCUITS}

\author{
O. S a mohvalova \\ PhD, Professor* \\ E-mail: sam-ov@mail.ru \\ N. Grevt seva \\ $\mathrm{PhD}$, Associate Professor* \\ E-mail: nataver@yandex.ua \\ T. Brykova \\ Postgraduate Student* \\ E-mail: arizona19@mail.ru \\ A. Grigorenko \\ $\mathrm{PhD}$, Chief technologist \\ Ltd "Charivna mozaika"
}

Avtostradna str., 21-A, Kharkiv, Ukraine, 61038

E-mail: anzhegrig@yandex.ru

*Department of Bakery, Confectionary, Pasta and Food Concentrates Technology

Kharkiv State University of

Food Technology and Trade

Klochkivska str., 333, Kharkiv, Ukraine, 61051

\section{Introduction}

Governments of many countries are developing and implementing national programmes aimed at improval of the nutritional status of population. These programmes include production of everyday food enriched with physiologically functional ingredients. In terms of environmental degradation and economic crisis, such products are essential for the health and working abilities of citizens and for providing a decent future via improved nutrition of children and youth.

All population groups are fond of pastries, in particular butter biscuits that are traditionally made of high-quality wheat flour, margarine or other fats, sugar, and egg products. Although such biscuits contain much fat and a lot of carbohydrates and are devoid of biologically active substances. In this regard, introduction of useful ingredients - dietary fibre, polyphenolic compounds, minerals and vitamins - to the composition of biscuits has a beneficial effect on human health. Such components are abundant in raw plant materials, among which especially interesting is grape pomace (wine production waste). Ukraine is a wine-producing state due to favourable for growing grapes climatic conditions of southern regions and Transcarpathia. Annually, wineries of Ukraine accumulate large amounts of grape pomace after 
crushing grape varieties and processing wine materials in winemaking. Such pomace that consists of grape seeds, skins and rachis is a powerful source of dietary fibre (cellulose, hemicellulose, pectin substances, and lignin), polyphenols (anthocyanins, leuco-anthocyanins, catechins, flavonols, etc), macro- and micronutrients (potassium, calcium, magnesium, phosphorus, iron, zinc, silicon, and copper), vitamins (PP, C, and choline) [1, 2]. Since grape pomace is rapidly rotting, immediately after processing, grape pomace is subjected to drying. It is proved that the maximum content of flavonoids, anthocyanins, tannins and linoleic acid are preserved in pomace if it is dried at a temperature of $50-52{ }^{\circ} \mathrm{C}$ [3]. There exist well-established technologies of obtaining powders of grape pomace or its constituents seeds and skins with rachis remains. Special technologies allow separating seeds from pomace and obtaining valuable grape oil. Oilcake that remains after squeezing oil is dried and also crushed into powder.

In recent years, doctors [4-7], pharmacists [8-10] and cosmetologists $[11,12]$ have focused on grape processing products - oils, powders, and polyphenolic extracts. This is predetermined by a wide range of effects inherent in biologically active grape compounds that are successfully used for prevention, treatment, and rehabilitation of various illnesses, including cardiovascular, pulmonary and immune deficiency diseases. Food industry experts also do not overlook grape pomace. There exist studies of the use of grape additives in the production of food, including pasta [13], chicken nuggets [14], and confectionery $[15,16]$; but at present these research findings are hardly implemented in Ukraine. It should be noted that since powders are obtained of primary production waste, they tend to be low-cost and their use does not increase the cost of products.

Given the above mentioned, we can conclude that grape seed powders (obtained of seeds previously separated from grape pomace) are valuable and promising additives in pastry production: the use of such powders can enhance the ranges of mass produced and functionally purposed pastries.

\section{Analysis of the previous studies and formulation of the problem}

Recently, much attention has focused on increasing the biological value of biscuits. It is proposed to use various enriching substances derived from processing plant raw materials: carrot puree and carrot pomace powder [17-19], rowanberry flour and chokeberry cryopowder [20, 21], as well as Jerusalem artichoke, blueberry, viburnum, pumpkin and apple purees [22].

Among plant-based enriching additives, grape products are distinguished by high contents of biologically active substances (first of all, polyphenolic antioxidants). They are recommended to improve the quality and nutritional value of multi-layered sweets [23] as well as new bread varieties of wheat and combined rye-wheat flours [24]. Moreover, it has long been known that grape juice and powder enrich bakery products and confectionery with vital components and improve their qualities [25]. Some studies focus on the use of grape processing products in butter biscuit technologies. Thus, it is recommended to enrich biscuits with ground grape seeds in the ratio of $7-9 \%$ of the weight of flour [21]; grape seed extract [26] and grape pomace cryopowder - up to $5 \%$ of the weight of flour [27, 28]. Although such additives have some disadvantages: (1) particles of milled grape seeds are quite large and discernible in the structure of biscuits, (2) grape seed extract has a depleted composition since it contains only matter obtained in extraction, and (3) cryopowders are expensive because their production is complex and involves using liquid nitrogen. For these reasons, the developed technologies are not implemented on an industrial scale. Moreover, ground grape seeds and cryopowders are added in small amounts, which does not allow significant enriching flour products with biologically active substances.

It should be noted that study [27] used experimental cryopowders produced separately of different grape varieties, although, it is impossible to divide pomace into varieties at large modern wineries that process grape variety mixtures. Research on the use of powdered winery pomace that consists of a mixture of different grape varieties is new. There is neither systematic understanding of the impact of such powders on properties of wheat flour, dough, and the nutritional value of bakery products, no recommendations on their rational dosages. Therefore, the current study focuses on these topical issues.

\section{The purpose and objectives of the study}

The purpose of the research is to determine the rational dosage of grape seed powder in the technology of butter biscuits enriched with biologically active substances.

To achieve the above goal we set the following tasks:

(1) to investigate the effect of grape seed powder on the properties of wheat flour gluten,

(2) to study the technological properties of the experimental powder, namely its water absorption capacity,

(3) to identify changes in physicochemical and organoleptic characteristics of the quality of butter biscuits enriched with grape seed powder.

\section{Materials and methods of the research}

Materials of the research include bakery wheat flour, grape seed powder (producer Oleo Vita company, Odesa, Ukraine), and butter biscuits with and without grape seed powder.

The effect of grape seed powder on the gluten amount, elasticity, extensibility and hydration ability was determined by methodology [29], whereas water absorption capacity of wheat flour and grape seed powder - by methodology described in [30].

Baked biscuits were cooled to a temperature of $18-20{ }^{\circ} \mathrm{C}$, then their quality was assessed in terms of physicochemical (specific volume and dampness), as well as organoleptic (appearance, texture, taste, color, and smell) characteristics [30].

The wetting ability of biscuits was determined by identifying an increase in their weight after immersion in water at $20^{\circ} \mathrm{C}$ during a specified time. The wetting index was determined with the use of a special cage with a door of stainless metal grid made of wire (diameter $-0.5 \mathrm{~mm}$ ) and the size of holes below $2 \mathrm{~mm}^{2}$.

The experiment started with measuring the weight of the wet empty cage. For this purpose, after the cage was immersed in a vessel with water and removed from it, the 
water was allowed to drain off, the cage was wiped from the outside, and then weighed.

An intacit biscuit was placed in the cage section and weighed on technical scales. Then the cage was immersed in a water vessel at a temperature of $20^{\circ} \mathrm{C}$ for 2 minutes. Once the cage was removed from the water, it was kept for $30 \mathrm{sec}-$ onds in an inclined position and weighed together with the wet biscuit. The wetting ability of biscuits was determined as the quotient of the difference between weight values of the cage with a wet product and the wet empty cage by the difference between weight values of the cage with a dry product and the wet empty cage.

\section{The research findings on the water absorption capacity of grape seed powder and its effect on the properties of gluten and the quality of butter biscuits}

The production of dough for butter biscuits requires flour with a low content of weak gluten. Therefore, we have studied the effect of grape seed powder on the properties of wheat flour gluten. It was added to flour in the following amounts: $5.0 \%, 10.0 \%, 15.0 \%$, and $20.0 \%$. The research findings are presented in Table 1.

Table 1

The effect of grape seed powder on the properties of wheat flour gluten

\begin{tabular}{|c|c|c|c|c|c|c|c|}
\hline № & \begin{tabular}{|c|} 
Power \\
dosage, \\
$\%$ of the \\
weight \\
of flour \\
\end{tabular} & \begin{tabular}{|c|} 
The \\
content \\
of raw \\
gluten, \\
$\%$
\end{tabular} & $\begin{array}{c}\text { Mass } \\
\text { fraction } \\
\text { of mois- } \\
\text { ture, } \%\end{array}$ & $\begin{array}{l}\text { Hydra- } \\
\text { tion } \\
\text { ability, \% }\end{array}$ & Colour & $\begin{array}{c}\text { Exten- } \\
\text { sibility, } \\
\mathrm{cm}\end{array}$ & $\begin{array}{l}\text { IDC } \\
\text { index }\end{array}$ \\
\hline 1 & \begin{tabular}{|c|c}
0 (refe- \\
rence)
\end{tabular} & $22.4 \pm 1.1$ & $65.7 \pm 3.2$ & $191.5 \pm 9.5$ & Cream & 13.0 & 82 \\
\hline 2 & 1.0 & $22.2 \pm 1.1$ & $65.2 \pm 3.2$ & $182.5 \pm 9.0$ & \multirow{4}{*}{$\begin{array}{l}\text { Light } \\
\text { brown }\end{array}$} & 12.9 & 80 \\
\hline 3 & 2.0 & $22.0 \pm 1.1$ & $64.7 \pm 3.1$ & $171.8 \pm 8.5$ & & 12.7 & 78 \\
\hline 4 & 3.0 & $21.9 \pm 1.0$ & $64.0 \pm 3.0$ & \begin{tabular}{|l|}
$166.5 \pm 8.0$ \\
\end{tabular} & & 12.5 & 75 \\
\hline 5 & 4.0 & $21.7 \pm 1.0$ & $62.8 \pm 3.0$ & $161.7 \pm 8.0$ & & 12.3 & 71 \\
\hline 6 & 5.0 & $21.5 \pm 1.0$ & $61.2 \pm 3.0$ & $157.7 \pm 7.7$ & \multirow{8}{*}{$\begin{array}{l}\text { Choco- } \\
\text { late }\end{array}$} & 12.0 & 67 \\
\hline 7 & 6.0 & $20.9 \pm 1.0$ & $59.8 \pm 2.9$ & $148.8 \pm 7.3$ & & 11.0 & 56 \\
\hline 8 & 7.0 & $20.1 \pm 1.0$ & $57.4 \pm 2.8$ & $134.7 \pm 6.6$ & & 10.5 & 54 \\
\hline 9 & 8.0 & $19.5 \pm 0.9$ & $54.3 \pm 2.7$ & $118.8 \pm 5.4$ & & 10.0 & 49 \\
\hline 10 & 9.0 & $18.8 \pm 0.9$ & $50.6 \pm 2.5$ & $102.4 \pm 5.0$ & & 9.2 & 47 \\
\hline 11 & 10.0 & \begin{tabular}{|l|}
$18.1 \pm 0.9$ \\
\end{tabular} & $47.3 \pm 2.3$ & $89.8 \pm 4.4$ & & 8.5 & 44 \\
\hline 12 & 11.0 & $17.5 \pm 0.8$ & $45.1 \pm 2.2$ & $82.1 \pm 4.1$ & & 8.0 & 41 \\
\hline 13 & 12.0 & $16.9 \pm 0.8$ & $41.1 \pm 2.0$ & $69.8 \pm 3.3$ & & 7.7 & 30 \\
\hline 14 & 13.0 & \multicolumn{6}{|c|}{ Unwashable } \\
\hline
\end{tabular}

Analysis of the presented data shows that adding grape seed powder to flour lowers gluten output. Thus, adding $5.0 \%$ of powder reduces gluten content by $4.0 \%$ (as compared to the reference sample) and adding $12.0 \%$ - by $24.6 \%$. If $13.0 \%$ of grape seed powder is added, gluten becomes unwashable. Lower "raw" gluten probably results from the negative effect of the additive on water-retaining capacity of fibrous proteins.

The quality of gluten also significantly changes with an increase of the additive fraction. Thus, adding $5.0 \%$ of powder decreases the IDC index by $18.3 \%$ (as compared to the reference sample) and makes gluten quality satisfactory, whereas adding $12.0 \%$ of grape seed powder reduces the
IDC index by $63.4 \%$ and makes the gluten quality poor the latter becomes too strong.

Meanwhile, extensibility of flour gluten gradually decreases. Adding $13.0 \%$ of powder strengthens the gluten so that it becomes tearable into small bits, and further increasing the additive concentration results in gluten becoming unwashable and crumbling into small pieces. Therefore, adding over $12.0 \%$ of grape seed powder to dough ensures loose structure of butter biscuits.

Strengthening effect of grape seed powder on the structure of gluten probably results from relatively high contents of non-starch polysaccharides, tannins and other polyphenols that interact with proteins to form complex compounds. In addition, a large number of oxidizing substances that are contained in powder is likely to lead to oxidation of sulfhydryl groups to disulfide ones with intermolecular bridges [18]. Thus, when grape seed powder is added, changes in the ratios of the above groups (among other reasons) significantly strengthen gluten structure. Chocolate colouration of gluten also confirms the assumption of the formation of complexes between flour proteins and powder components.

It is known that polymers with higher hydrophilic properties can bind more water and to some extent affect the course of colloid as well as physicochemical processes that occur during dough mixing. Therefore, water absorption capacities of grape seed powder and wheat flour were determined in accordance with the temperature: swelling time was $10 \mathrm{~min}$ at 30,60 , and $90^{\circ} \mathrm{C}$. The findings (Fig. 1) show that at a temperature of $30^{\circ} \mathrm{C}$, water absorption coefficient of wheat flour is 3 times lower than that of powder (0.63 vs. 1.90). Therefore, during dough formation, biopolymers of grape seed powder and highly hydrophilic components of flour compete in water absorption, which promotes dough compaction. With the rise in temperature to $60^{\circ} \mathrm{C}$, water absorption coefficient of powder almost does not change, and that of wheat flour increases twice, which is explained by the beginning of starch pasting and a higher degree of its swelling. At a temperature of $30^{\circ} \mathrm{C}$, pasted starch binds a maximum amount of water, which increases the water absorption coefficient of wheat flour almost 3 times (as compared to $30^{\circ} \mathrm{C}$ ) and makes it close to the water absorption capacity of powder.

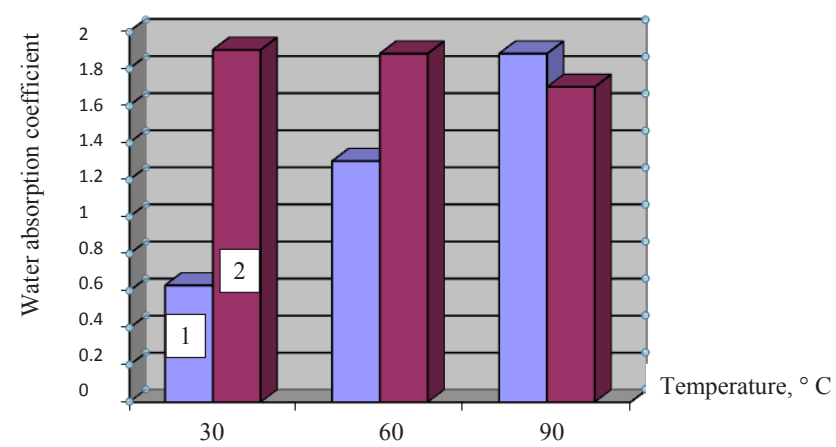

Fig. 1. Water absorption capacities of wheat flour and grape seed powder: 1 - Wheat flour; 2 - Grape seed powder

The experimental additive can lead to compaction of butter biscuit dough during its mixing, which should be taken into account when dough is machined, although it positively affects the structure of baked products.

The study of the effect of grape seed powder on the quality of butter biscuits was based on the traditional technology 
of butter biscuits jigging, which comprises the following main stages: preparing raw stuff, preparing an emulsion of sugar, eggs, and butter, mixing dough, forming biscuits, baking, and cooling baked products.

Due to the peculiar chemical composition and antioxidant properties of grape seed powder, it can help to extend the shelf life of fat-containing products; therefore, the selected additive was introduced at the stage of emulsion formation. The powder is characterized by appropriate technological properties - it is fine-dispersed, easily shared between components of an egg-sugar-oil emulsion, does not form lumps, and provides a uniform chocolate colour. In terms of food and biological value of butter biscuits, concentration of grape seed powder should be maximum possible. Therefore, it was added in amounts of $10.0-20.0 \%$ of the weight of flour.

The research findings on physicochemical parameters of the quality of butter biscuits with grape pomace powder are shown in Table 2.

It is found (Table 2) that adding grape seed powder to butter biscuits almost does not affect physicochemical indices of the latter.

Table 2

The effect of grape seed powder on the quality of butter biscuits

\begin{tabular}{|c|c|c|c|}
\hline $\begin{array}{c}\text { The amount of } \\
\text { powder, \% of } \\
\text { the weight of } \\
\text { flour }\end{array}$ & Moisture, \% & $\begin{array}{c}\text { Specific } \\
\text { volume, } \mathrm{cm}^{3} / \mathrm{g}\end{array}$ & $\begin{array}{c}\text { Wetting } \\
\text { ability, \% }\end{array}$ \\
\hline 0 (reference) & $4.5 \pm 0.2$ & $1.78 \pm 0.07$ & $150 \pm 6.1$ \\
\hline 10 & $4.5 \pm 0.2$ & $1.76 \pm 0.07$ & $148 \pm 6.2$ \\
\hline 15 & $4.7 \pm 0.2$ & $1.72 \pm 0.07$ & $146 \pm 5.5$ \\
\hline 20 & $5.0 \pm 0.1$ & $1.65 \pm 0.07$ & $140 \pm 5.8$ \\
\hline
\end{tabular}

Adding powder in a quantity within the experimental range slightly reduces the specific volume of biscuits - by $1.1-3.4 \%$ (as compared to the reference sample), which is within the margin of error. Adding $20.0 \%$ of powder reduces the specific volume of biscuits by $7.3 \%$. When $10.0-15.0 \%$ of powder is added, the wetting ability decreases by $1.3-2.7 \%$, and if we add $20.0 \%$ of powder, - by $6.7 \%$, i. e. adding $10.0 \%$ and $15.0 \%$ of powder has little effect on the looseness of biscuits (which is indirectly proved by the indices of specific volume and wetting ability), whereas adding $20.0 \%$ of powder leads to a slight compaction of the ready products.

Thus, adding up to $15.0 \%$ of grape seed powder to butter biscuits does not result in changes of the quality indices, whereas increasing the additive concentration to $20.0 \%$ slightly degrades it.

The research findings on organoleptic properties of butter biscuits with and without grape seed powder are shown in Table 3.

Table 3 shows that adding up to $15.0 \%$ (of the weight of flour) of grape seed powder does not degrade organoleptic properties of butter biscuits - they do not differ from the reference ones. Only colour changes - it becomes light brown. Increasing powder concentration up to $20.0 \%$ thickens the structure of biscuits making them firm and slightly tight.

Therefore, it is useful to add grape seed powder to butter biscuits in order to enrich the latter with biologically active compounds if the concentration of powder does not exceed
$15.0 \%$ of the weight of flour. This will increase the biological value of biscuits and preserve their quality.

Table 3

The effect of grape seed powder on organoleptic properties of butter biscuits

\begin{tabular}{|c|c|c|c|c|}
\hline \begin{tabular}{|c|} 
The amount \\
powder, \% of \\
the weight \\
of flour
\end{tabular} & Appearance & Colour & Taste, smell & Texture \\
\hline 0 (reference) & $\begin{array}{l}\text { The set form } \\
\text { is preserved, } \\
\text { without } \\
\text { fractures, } \\
\text { bubbles, or } \\
\text { cracks }\end{array}$ & Golden & $\begin{array}{c}\text { Pleasant, } \\
\text { typical } \\
\text { of freshly } \\
\text { baked butter } \\
\text { biscuits, free } \\
\text { from foreign } \\
\text { tastes and } \\
\text { odours }\end{array}$ & $\begin{array}{l}\text { Crumbly, } \\
\text { loose, free from } \\
\text { undispersed } \\
\text { traces, with an } \\
\text { even fracture } \\
\text { porosity }\end{array}$ \\
\hline 10 & \multirow{3}{*}{$\begin{array}{l}\text { The set form } \\
\text { is preserved, } \\
\text { without } \\
\text { fractures, } \\
\text { bubbles, or } \\
\text { cracks }\end{array}$} & $\begin{array}{l}\text { Light } \\
\text { brown }\end{array}$ & \multirow{3}{*}{$\begin{array}{c}\text { Pleasant, } \\
\text { typical } \\
\text { of freshly } \\
\text { baked butter } \\
\text { biscuits, free } \\
\text { from foreign } \\
\text { tastes and } \\
\text { odours }\end{array}$} & $\begin{array}{l}\text { Crumbly, } \\
\text { loose, free from } \\
\text { undispersed }\end{array}$ \\
\hline 15 & & \multirow[b]{2}{*}{ Chocolate } & & $\begin{array}{c}\text { traces, with an } \\
\text { even fracture } \\
\text { porosity }\end{array}$ \\
\hline 20 & & & & $\begin{array}{l}\text { Dense, slightly } \\
\text { tight, free from } \\
\text { undispersed } \\
\text { traces }\end{array}$ \\
\hline
\end{tabular}

\section{Discussing the research findings on the possibility of using grape seed powder in butter biscuit technologies}

The research findings on the effect of grape seed powder on the properties of fibrinous proteins of wheat flour prove that adding grape seed powder to flour in the experimental doses makes gluten less tensile and more elastic. This can negatively affect the quality of products of shortcrust, biscuit and butter biscuit dough varieties. Since the structure of the corresponding products can be firm and dense instead of being crumbly and soft, study [1] recommends an amount of $1.0-5.0 \%$ (of the wheat flour weight) of powdered grape pomace, including powdered grape seed. Although Table 1 shows that adding experimental powder in an amount of $13.0 \%$ and more significantly strengthens the gluten making it brittle, crumbling and unwashable. This change in the properties of gluten suggests that butter biscuit dough will not be dense, and its products are likely to have a soft and crumbly texture.

The findings on water absorption capacity of grape seed powder presented numerically and graphically in Fig. 1 prove that adding powder can affect the process of dough formation during cooking butter biscuits. A three-time higher water absorption capacity of the experimental powder (as compared to wheat flour at a temperature of $30^{\circ} \mathrm{C}$, i. e. approximately under conditions of dough kneading/machining) causes competition for water between flour biopolymers and powder non-starch polysaccharides. Lack of moisture previously absorbed by powder polysaccharides does not allow fibrinous protein swelling and fibrinous frame forming, which is prerequisite for the formation of a soft and crumbly structure of baked biscuits in this technology. It is also found that at a temperature of $90{ }^{\circ} \mathrm{C}$, i. e. under the conditions of baking finished products, water absorption capacity of grape seed powder is the same as that of wheat flour, and even a little lower. This can also be interpreted as a positive fact - 
the structures of baked reference and experimental samples of biscuits will have many differences.

To test the above assumptions, we have studied quality characteristics of butter biscuits and presented the findings in Tables 2, 3. We have proved that physicochemical parameters of the quality of butter biscuit samples enriched with grape pomace powder in an amount of up to $15.0 \%$ of the weight of flour are very similar to the reference samples: they have the same specific volume and wetting ability. Increasing the amount of additive to $20.0 \%$ really degrades the structure of biscuits, leads to their compaction, as evidenced by the reduced indices of specific volume and wetting ability.

Enriching additives can cause undesirable deterioration in organoleptic properties of flour products. Assessment of all the samples of butter biscuits (Table 3) shows that biscuits with grape seed powder in an amount of up to $15.0 \%$ are characterized by pleasant appearance, colour, taste, smell, and texture.

Therefore, the analysis and synthesis of the obtained experimental data prove the reasonability of enriching butter biscuits with grape seed powder. The rational dosage of powder is $15.0 \%$ of the weight of wheat flour. It provides high quality of products that contain polyphenolic compounds, dietary fibre, minerals and vitamins that are abundant in the experimental powder. A perspective research on the chemi- cal composition of designed products is likely to complete the description of the biological value of new butter biscuits with grape seed powder additives.

\section{Conclusions}

1. Adding grape seed powder to wheat flour lowers the output gluten, reduces its tensibility and increases elasticity. In butter biscuit technologies, the recommended amount of powder is $13.0 \%$ and more, since this concentration of the additive makes gluten unwashable and dispersible into small bits, which provides a crumbly structure of biscuits.

2. Water absorption capacity of grape seed powder at a temperature of $30^{\circ} \mathrm{C}$ is three times higher than that of wheat flour, which prevents fibrinous protein swelling and fibrinous frame forming. At a temperature of $90^{\circ} \mathrm{C}$, water absorption capacity of grape seed powder is the same as that of wheat flour and even a little lower, which positively affects the structure of ready biscuits.

3. Adding $15.0 \%$ of grape seed powder to butter biscuits improves their physicochemical (specific volume and wetting ability) as well as organoleptic quality indices, although increasing the additive concentration to $20.0 \%$ slightly deteriorates them; i.e. the rational dosage of the experimental additive is $15.0 \%$ of the weight of wheat flour.

\section{References}

1. Lisjuk, G. M. Novi naprjami vikoristannja vtorinnih produktiv pererobki vinogradu u virobnictvi boroshnjanih virobiv [Text]: monografija / G. M. Lisjuk, N. V. Vereshko, A. M. Chujko. - Kharkiv: HDUHT, 2011. - 175 p.

2. Bareeva, N. N. Vinogradnye vyzhimki - perspektivnyj promyshlennyj istochnik pektinovyh veshhestv [Electronic resource] / N. N. Bareeva, L. V. Donchenko. - Available at: http://ej.kubagro.ru/2006/04/30/

3. Bat'kova, I. A. Vlijanie temperatury sushki na himicheskij sostav i antioksidantnye svojstva vinogradnyh vyzhimok [Text] / I. A. Bat'kova, I. A. Jashina, N. V. Makarova, M. N. Novikova, N. V. Smirnova // Hranenie i pererabotka sel'hozsyr'ja. - 2014 Vol. 2. - P. 36-38.

4. Holcombe, R. F. Results of a phase I pilot clinical trial examining the effect of plant-derived resveratrol and grape powder on Wnt pathway target gene expression in colonic mucosa and colon cancer [Text] / R. F. Holcombe, A. V. Nguyen, M. Martinez, M. J. Stamos, M. P. Moyer, K. Planutis et. al. // Cancer Management and Research. - 2009. - P. 25-37. doi: 10.2147/cmr.s4544

5. Suwannaphet, W. Preventive effect of grape seed extract aginst high-fructose diet-induced unsulin resistance and oxidative stress in in rats [Text] / W. Suwannaphet, A. Meeprom, S. Yibchok-Anun, S. Adisakwattana // Food and Chemical Toxicology. - 2010. Vol. 48, Issue 7. - P. 1853-1857. doi: 10.1016/j.fct.2010.04.021

6. Salim, S. The Role of Grape Powder in Emotional Well-Being and Memory Improvement [Text] / S. Salim, G. Patki, B. Jannise. Diet and Nutrition in Dementia and Cognitive Decline, 2015. - P. 925-934. doi: 10.1016/b978-0-12-407824-6.00085-9

7. Tkachenko, A. I. Vinograd - venec tvorenija prirody. Nauchno-metodicheskoe posobie dlja vrachej i shirokogo kruga chitatelej [Text] / A. I. Tkachenko. - Kharkiv: Nauchno-lechebnyj fitocentr «Avicenna», 2009. - 28 p.

8. Sagindykova, B. A. Razrabotka tabletok s suhim jekstraktom semjan vinograda s modificirovannym vysvobozhdeniem [Text] / B. A. Sagindykova, A. I. Tihonov, D. S. Isabekova // Visnik farmacii. - 2011. - Vol. 1 (65). - P. 16-19.

9. Voronina, L. M. Polifenol'ni ekstrakty vynogradu kul'turnogo na zahysti pechinky za umov oksydatyvnogo stresu [Text] / L. M. Voronina, A. L. Zagajko, A. S. Samohin, L. M. Aljeksjejeva // Klinichna farmacija. - 2004. - Vol. 8, Issue 2. - P. 36-37.

10. Grape Extracts May Be Effective Against Harmful Gut Bacteria [Electronic resource]. - Available at: https://www.sciencedaily. com/releases/2009/03/090304132621.htm

11. Pticyn, A. R. Tehnologija vydelenija flavonoidov vinograda Vitis vinifera sorta «Izabella» dlja kosmetiki i izuchenie ih svojstv [Text] avtoref. dis. ... kand. him. nauk / A. V. Pticyn. - Moscow, 2007. - 26 p.

12. Bondakova, M. V. Razrabotka receptury i tehnologii proizvodstva kosmeticheskih izdelij s ispol'zovaniem jekstrakta vinograda [Text]: avtoref. dis. ... kand. tehn. nauk / M. V. Bondakova. - Moscow, 2014. - 23 p.

13. Sant'Anna, V. The effect of the incorporation of grape marc powder in fettuccini pasta properties [Text] / V. Sant'Anna, F. D. P. Christiano, L. D. F. Marczak, I. C. Tessaro, R. C. S. Thys // LWT - Food Science and Technology. - 2014. - Vol. 58, Issue 2. - P. 497-501. doi: 10.1016/j.lwt.2014.04.008

14. Cagdas, E. Effect of grape seed powder on oxidative stability of precooked chicken nuggets during frozen storage [Text] / E. Cagdas, S. Kumcuoglu // Journal of Food Science and Technology. - 2015. - Vol. 52, Issue 5. - P. 2918-2925. doi: 10.1007/s13197-014-1333-7 
15. Aksoylu, Z. Effects of Blueberry, Grape Seed Powder and Poppy Seed Incorporation on Physicochemical and Sensory Properties of Biscuit [Text] / Z. Aksoylu, Ö. Çağindi, E. Köse // Journal of Food Quality. - 2015. - Vol. 38, Issue 3. - P. 164-174. doi: 10.1111/ jfq.12133

16. Kalinovs'ka, T. V. Vykorystannja vtorynnyh produktiv pererobky vynogradu pid chas rozrobky innovacijnyh tehnologij kondyters'kyh vyrobiv [Text]: temat. zb. nauk. pr. / T. V. Kalinovs'ka, I. O. Krapyvnyc'ka, V. I. Obolkina, S. G. Kyjanycja // Obladnannja ta tehnologii' harchovyh vyrobnyctv. - Donec'kyi nacional'nyi universytet ekonomiky i torgivli im. M. Tugan-Baranovs'kogo. - 2013. - Vol. 30. - P. 75-80.

17. Pat. 72163 Ukrai'na, MPK (2012.01) A 23 G 3/00. Sposib vyrobnyctva biskvitno-zbyvnogo zdobnogo pechyva «Shantane» [Text] / Obolkina V. I., Kyrpichenkova O. M., Bukshyna L. S., Krapyvnyc'ka I. O. - zajavnyk ta patentovlasnyk Nacional'nyj universytet harchovyh tehnologij. - № u201200701 ; zajavl. 23.01.2012 ; opubl. 10.08.2012, Bjul. № 15. - 3 p.

18. Pat. 89005 Ukrai'na, MPK (2014.01) A 21 D 2/00. Pisochne pechyvo «Sonechko» [Text] / Zadorozhnja O. S., Gavrysh A. V., Docenko V. F. - zajavnyk ta patentovlasnyk Nacional'nyj universytet harchovyh tehnologij. - № u201312347 ; zajavl. 21.10.2013; opubl. 10.04.2014, Bjul. № 7. - 2 p.

19. Pat. 57628 Ukrai'na, MPK (2011.01) A 23 G 3/36. Zdobne pechyvo [Text] / Korec'ka I. L., Lytvyn G. V., Bandurenko G. M., Levkivs'ka T. M., Zinchenko T. V. - zajavnyk ta patentovlasnyk Nacional'nyj universytet harchovyh tehnologij. - № u201312347 ; zajavl. 21.10.2013; opubl. 10.04.2014, Bjul. № 7. - 2 p.

20. Pat. 94940 Ukrai'na, MPK (2006.01) A 21 D 13/08. Sklad pisochnogo pechyva «Aronija» [Text] / Jablons'ka I. O., Myroshnyk Ju. A., Gavrysh A. V, Docenko V. F. - zajavnyk ta patentovlasnyk Nacional'nyj universytet harchovyh tehnologij. № u201405677; zajavl. 26.05.2014; opubl. 10.12.2014, Bjul. № 23. - 2 p.

21. Pat. 35281 Ukrai'na, MPK (2006) A 21 D 13/00. Zdobne pechyvo «Spokusa» [Text] / Syrohman I. V., Turchynjak M. K. - zajavnyk ta patentovlasnyk Syrohman I. V., Turchynjak M. K. - № u200804704; zajavl. 11.04.2008; opubl. 10.09.2008, Bjul. № 17. - 3 p.

22. Syrohman, I. V. Asortyment i jakist' kondyters'kyh vyrobiv : navch. posibnyk [Text] / I. V. Syrohman, V. T. Lebedynec'. - Kyiv: Centr uchbovoi' literatury, 2009. - $636 \mathrm{p}$.

23. Kalinovskaya, T. V. Substantiation of using wine-making secondary products as alternative raw material for confectionery industry [Text] / T. V. Kalinovskaya, V. I. Obolkina // Nauka i Studia. - 2014. - Vol. 14, Issue 124. - P. 59-62.

24. Sidorenko, A. V. Tehnologicheskie osobennosti prigotovlenija hlebobulochnyh izdelij obogashhennyh poroshkom iz kozhicy vinogradnyh vyzhimok [Text] / A. V. Sidorenko, O. L. Vershinina, V. V. Derevenko, D. V. Shapovalova // Izvestija vuzov. Pishhevaja tehnologija. - 2011. - Vol. 4. - P. 26-28.

25. Drobot, V. I. Issledovanie vozmozhnosti primenenija produktov iz vinograda v hlebopechenii [Text] / V. I. Drobot, V. F. Docenko, L. Ju. Arsen'eva, Ju. V. Ustinov, N. A. Pereguda. - Kyiv, 1987. - 10 p.

26. Davidov-Pardo, G. Sensory and Consumer Perception of the Addition of Grape Seed Extracts in Cookies [Text] / G. DavidovPardo, M. Moreno, I. Arozarena, M. R. Marin-Arroyo, R. N. Bleibaum, C. M. Bruhn // Journal of Food Science. - 2012. - Vol. 77, Issue 12. - P. 430-438. doi: 10.1111/j.1750-3841.2012.02991.x

27. Chujko, A. M. Research of quality of yeast-leavened dough products and shortbread using cryopowders made of herbal raw materials [Text] / A. M. Chujko, M. M. Chujko, O. S. Orlova, S. O. Jer'omenko // Eastren-European Journal of Enterprise Technologies. 2014. - Vol. 2, Issue 12 (68). - P. 133-137. doi: 10.15587/1729-4061.2014.22416

28. Maner, S. Wheat Flour Replacement by Wine Grape Pomace Powder Positively Affects Physical, Functional and Sensory Properties of Cookies [Text] / S. Maner, A. K. Sharma, K. Banerjee // Proceedings of the National Academy of Sciences, India - Section B: Biological Sciences. - 2015. doi: 10.1007/s40011-015-0570-5

29. Drobot, V. I. Laboratornyj praktykum z tehnologii' hlibopekars'kogo ta makaronnogo vyrobnyctv [Text]: navch. pos. / V. I. Drobot. - Kyiv: Centr navchal'noi' literatury, 2006. - 341 p.

30. Lur'e, I. S. Tehnologija i tehnohimicheskij kontrol' konditerskogo proizvodstva [Text] / I. S. Lur'e. - Moscow: Ljogkaja i pishhevaja promyshlennost', 1981. $-328 \mathrm{p}$. 